\title{
SPEECH ACT ANALYSIS OF “FROZEN" THE MOVIE SCRIPT
}

\author{
Adinda Srimulya Rahayu' ${ }^{1}$, Trisnendri Syahrizal ${ }^{2}$, Irma Savitri Sadikin ${ }^{3}$ \\ ${ }^{1}$ IKIP Siliwangi \\ ${ }^{2}$ IKIP Siliwangi \\ ${ }^{3}$ IKIP Siliwangi \\ ${ }^{1}$ adindasr1608@gmail.com, ${ }^{2}$ trisnendri@ikipsiliwangi.ac.id, ${ }^{3}$ savitrisadikin@gmail.com
}

\begin{abstract}
This research aimed to analyze the speech acts of the movie script entitled Frozen, the movie that is being the most popular movie in 2013 until now. The research design in this paper is a qualitative method where the writers describe the result in a form of the words and the explanation of the result. The writers analyze all types of speech acts (representatives, commissives, directives, declarations, expressives, verdictives) by Finegan (2011) in doing this research, as the results of this research, all of the types of speech acts had their own meaning for delivering the sentences to make such a response. The writers found 294 clauses that contain the type of speech acts, there are representatives (37), commissives (3), directives (32), expressives (10). Each type of the speech acts are delivering different meaning. The results of the research are taken from the script of the character named Anna in Frozen the movie.
\end{abstract}

Keywords: Pragmatic, Language, Speech Act, Movie

\section{INTRODUCTION}

Language is the communication form that is used by a human as Johnson (2008) in Kiuk and Ghozali (2018:60) who claims that language is the process or set of process used to ensure there is agreement between the sender and receiver for meanings assigned to the symbol and the schema for combining them used for each communication. We deliver our thoughts to other by using the sign, there is a study about the sign called pragmatic. Pragmatic is the train of the word by studying the sign of the words. Griffiths (2006) in Lisdawati and Syahrizal (2012:3) describes that pragmatics is about the interaction of semantic knowledge with our knowledge of the world, taking into account contexts of use. What being analyzes in pragmatic is the speech act. A speech act is an action that we use in the language, this statement is supported by Searle (1969) in Tauchid and Rukmini (2016:3) who states that "the theory of speech act starts with the assumption that the minimal unit of human communication is not a sentence or other expression, but rather the performance of certain kinds of acts, such as making statement, asking questions, giving orders, describing, explaining, apologizing, tanking, congratulating, etc."

Speech act falls into 3 classes that are locutionary, illocutionary and perlocutionary (Ilyas and Khushi 2012). And yet there are types of speech act, the first is representatives, representatives represent a state of concern: assertions, claims, hypotheses, descriptions, suggestions, representatives can usually be characterized as true or false, the second is commissives that commits a talker to a curse of action: promises, pledges, threats, vows, the third are directives that are meant to obtain the receiver to bring out an action: commands, requests, challenges, invitations, entreaties, dares, the fourth is declarations that carry out about the situation of events they name: blessings, hirings, firings, baptisms, arrests, marryings, declaring mistrials, the fifth is Expressives, expressives show the speaker's psychological state or manner: 
greetings, apologies, congratulations, condolences, thanksgivings, and the last is Verdictives, verdictives make assessments or judgments: ranking, assessing, appraising, condoning. (Finegan, 2011:304).

\section{METHOD}

The writers use a qualitative research design to analyze the speech acts of Frozen the Movie script because this research are analyzing the words and word form by mentioning the sentence and its type of speech acts. According to Perry (2005) cited in Dewi, Hernawan \& Apsari (2019), qualitative research is characterized by the verbal description of its data. The data was taken from movie script of Frozen. The script was written by Jennifer Lee in 2013, Frozen the movie is one of the most interesting fantasy 3D movie by Walt Disney Pictures. This story is about a kingdom that gets trapped in eternal winter. Then the writers analyzed the type of speech acts found in frozen movie script as proposed by Finegan (2011:304).

Merriam (1966) in Creswell (1997:145) claims that qualitative research is descriptive in that the researcher is fascinated in process, meaning, and understanding obtained through words or figure. In this analysis, the writers used the script of one character that has a role as the main character named Anna.

\section{RESULTS AND DISCUSSION}

\section{A. Results}

Based on the script that has been observed, the data can be seen in the table below:

Table 1. Speech act result in Frozen the Movie script

\begin{tabular}{cc}
\hline Speech act & Amount/sentences \\
\hline Representatives & $37 / 294$ \\
\hline Commissives & $3 / 294$ \\
\hline Directives & $32 / 294$ \\
\hline Declarations & $0 / 294$ \\
\hline Expressives & $10 / 294$ \\
\hline Verdictives & $0 / 294$ \\
\hline
\end{tabular}

\section{B. Discussion}

Based on the findings, the writers found 4 language style in frozen the movie. Each data of the language style are taken by the sample of the sentences.

The data below are the types of speech act. The writers divided the sentence by the type of speech act by Finegan (2011).

\section{Representatives}

\section{Data 1}

I just can't. The sky's awake, so I'm awake, so we have to play.

The words in bold are representative because it shows that the speaker states a description that the sky is awake, awake here means that the night sky is bright because there an aurora in the sky. As Finegan (2011) said, representatives represent a state of concern of descriptions. On definition, we can see a relationship of it. This data 1 describe how the sky looks like and it regarded as description, representative. 


\section{Data 2}

Thank you. You look beautifuller. I mean, not fuller. You don't look fuller, but more beautiful.

The words in bold are representative because it shows that the speaker states a claim on saying something as she said beautifuller means more beautiful to her sister. As Finegan (2011) said, representatives represent a state of concern of claim. On definition, we can see a relationship of it. This data describes the beauty of her sister and it regarded as description of representative.

\section{Data 3}

Ha. This is awkward. Not you're awkward, but just because we're- I'm awkward. You're gorgeous.

The words in bold are representative because it shows that the speaker states a description of the situation, awkward describe the moment that she meets a prince in an unexpected moment. As Finegan (2011) said, representatives represent a state of concern of descriptions. As we can see a relationship of it. This data describes the the situation of the moment and it regarded as description of representative.

\section{Data 4}

I was born with it, although I dreamt I was kissed by a troll.

The words in bold are representative because it shows that the speaker states a claim on saying something as she claims that she was born with a white color in her little part of her hair, as Finegan (2011) said, representatives represent a state of concern of claims. On definition, we can see a relationship of it. This data describes the the past event and it regarded as description of representative.

\section{Data 5}

More than you. All you know is how to shut people out.

The words in bold are representative because it shows that the speaker states a claim on saying something as she said to her sister that her sister shut her out from they were a kid until the time they grow up, as Finegan (2011) said, representatives represent a state of concern of claims. On definition, we can see a relationship of it. This data describes what her sister do of all time and it regarded as description of representative.

\section{Data 6}

\section{Do you want to build a snowman?}

The words in bold are representative because it shows that the speaker states a hypothesis, the speaker asks her sister to build a snowman, as she knows that her sister can do magic, as Finegan (2011) said, representatives represent a state of concern of hypothesis. On definition, we can see a relationship of it. This data shows a hypotheses that she asks her sister to do something and it regarded as hypotheses of representative.

\section{Data 7}

Okay, just tell me one thing; what was happening on the North Mountain? Did it seem magical?

The words in bold are representative because it shows that the speaker states a hypothesis, the speaker aks the person in the store if he saw a magical event at the north mountain, as Finegan (2011) said, representatives represent a state of concern of 
hypothesis. On definition, we can see a relationship of it. This data shows a hypotheses that she asks the man from the north mountain who met her in a store in the middle of heavy snow and it regarded as hypotheses of representative.

\section{Data 8}

Yes. Pay attention. But the thing is she wore the gloves all the time, so I just thought, maybe she has a thing about dirt.

The words in bold are representative because it shows that the speaker states a hypothesis, the speaker guesses if her sister has a thing about dirt, a thing about dirt means she has an allergic to dirt because her sister wears gloves for most of the time, as Finegan (2011) said, representatives represent a state of concern of hypothesis. On definition, we can see a relationship of it. This data shows a hypotheses that she wonder why her sister always wear a gloves and it regarded as hypotheses of representative.

\section{Data 9}

\section{Olaf, did Elsa build you?}

The words in bold are representative because it shows that the speaker states a hypothesis, the speaker asks the snowman if she was built by her sister because when the speaker saw the snowman, the speaker remembers that when she was a kid, her sister build a snowman for her, as Finegan (2011) said that representatives represent a state of concern of hypothesis. On definition, we can see a relationship of it. This data shows a hypotheses that she asks her old friend and it regarded as hypotheses of representative.

\section{Data 10}

Oh, great. For now, how about boots. Winter boots... and dresses?

The words in bold are representative because it shows that the speaker gives a suggestion when the owner of the store offers a discount on summer item, the speaker needs a winter item because it is heavy snow outside and she wears only a dress, as Finegan (2011) said, representatives represent a state of concern of suggestions. On definition, we can see a relationship of it. This data shows a hypotheses that she asks the store owner about the stuff he has and it regarded as hypotheses of representative.

\section{Commissives}

\section{Data 1}

Whoa.... I'll replace your sled and everything in it.

The words in bold are commissive because it shows that the speaker promises something, at this moment the speaker jumps with her friend's sled and broke it, so she promises that she will replace her friend's sled, as Finegan (2011) said that commissives commit a talker to a curse of action promises. On definition, we can see a relationship of it. This data shows a promises that she said to the man to replace the sled with a new one and it regarded as a promises in commissives.

\section{Data 2}

But it'll be fine. Elsa will thaw it.

The words in bold are commissive because it shows that the speaker promises something when the speaker and her friend walk along the upper mountain and her friend says that the Arendelle is in deep snow, the speaker promises that her sister will thaw the snow with her magic, as Finegan (2011) said that commissives commit a talker to a curse of action promises. On definition, we can see a relationship of it. This data shows a 
promises that she promises that the condition in Arendele will be fine and it regarded as a promises in commissives.

\section{Directives}

\section{Data 1}

\section{Bring me my horse, please.}

The words in bold are directive because it shows that the speaker states a command when she intends to go to the mountain in order to meet her sister that ran away, she asks the servant to get the horse to take her up the mountain, as Finegan (2011) said that directives are meant to obtain the receiver to bring out an action: e.g. commands. On definition, we can see a relationship of it. This data shows a command to the servant to bring a horse to accompany her to go find her sister and it regarded as a command in directives.

\section{Data 2}

\section{No, I need you here to take care of Arendelle.}

The words in bold are directive because it shows that the speaker states a command when the prince of another kingdom wants to follow her in sister's search, she commands the prince to stay in Arendelle to take care of it, as Finegan (2011) said that directives are meant to obtain the receiver to bring out an action: e.g. commands. On definition, we can see a relationship of it. This data shows a command to the prince from southern island to not following her and stay in arendelle and it regarded as a command in directives.

\section{Data 3}

\section{We leave now. Right now.}

The words in bold are directive because it shows that the speaker states a command to her friend to accompany her to the north mountain with his sled and reindeer, it was at night with a heavy snow when the speaker asks her friend to go, as Finegan (2011) said that directives are meant to obtain the receiver to bring out an action: e.g. commands. On definition, we can see a relationship of it. This data shows a command to the man to go immediately to see her sister and it regarded as a command in directives.

\section{Data 4}

You have to. No return. No exchanges. Queen's orders. She's named you the official Arendelle Ice Master and Deliverer.

The words in bold are directive because it shows that the speaker states a command because she is a princess and her sister is a queen, finally the queen replaced his sled with a new one, but her friend rejected that, so the speaker as the princess said that there is no return and exchange, as Finegan (2011) said that directives are meant to obtain the receiver to bring out an action: e.g. commands. On definition, we can see a relationship of it. This data shows a command to the man to receive a present from her and the queen and it regarded as a command in directives.

\section{Data 5}

\section{Do the magic! Do the magic!}

The words in bold are directive because it shows that the speaker states a command to her sister to do the magic, that is, to make a snow and play together in the middle of the night, as Finegan (2011) said that directives are meant to obtain the receiver to bring out 
an action: e.g. commands. On definition, we can see a relationship of it. This data shows a command to her sister to play with her and it regarded as a command in directives.

\section{Data 6}

\section{Elsa! Wait, please!}

The words in bold are directive because it shows that the speaker states a request, as the speaker requests to her sister to wait and do not run away, as Finegan (2011) said that directives are meant to obtain the receiver to bring out an action: e.g. request. On definition, we can see a relationship of it. This data shows a request to her sister that ran away and the speaker wants to stop it and it regarded as a request in directives.

\section{Data 7}

\section{Take me up the North Mountain... Please.}

The words in bold are directive because it shows that the speaker states a request to her friend to take her up the north mountain to meet her sister, as Finegan (2011) said that directives are meant to obtain the receiver to bring out an action: e.g. request. On definition, we can see a relationship of it. This data shows a request to the man to accompany her to the north mountain with his reindeer and sled and it regarded as a request in directives.

\section{Data 8}

\section{Please, somebody help.}

The words in bold are directive because it shows that the speaker states a request when she was left alone in a room with a white hair and cold body, while the door is locked and she screams with her low voice to get a help to get out of the room and meet her sister, as Finegan (2011) said that directives are meant to obtain the receiver to bring out an action: e.g. request. On definition, we can see a relationship of it. This data shows that the speaker requests something to somebody to help her out when she began to freeze and it regarded as a request in directives.

\section{Data 9}

\section{Help me up, Olaf. Please.}

The words in bold are directive because it shows that the speaker states a request to the snowman when he finally opened the locked door and get into the room, the speaker wishes to be taken out from the room, as Finegan (2011) said that directives are meant to obtain the receiver to bring out an action: e.g. request. On definition, we can see a relationship of it. This data shows a request to her friend to help her out when she began to freeze and wanted to reach the fire in the fireplace and it regarded as a request in directives.

\section{Data 10}

\section{Please Olaf, you can't stay here...}

The words in bold are directive because it shows that the speaker states a request when the snowman finally opened the door and come to help her, but the snowman is spellbound because he lives in the snow and never see fire, as Finegan (2011) said that directives are meant to obtain the receiver to bring out an action: e.g. request. On definition, we can see a relationship of it. This data shows a request to her friend to go because her friend is made of ice and hhe stays in front of the firelace and began to melt and it regarded as a request in directives. 


\section{Expressives \\ Data 1}

Hi me...? Oh. Um. Hi.

The words in bold are expressive because it shows that the speaker expresses her greeting when she meets her sister after many years, and she feels awkward to meet her sister for the first time after many years, as Finegan (2011) said that expressives show the speaker's psychological state or manner: e.g. greetings. On definition, we can see a relationship of it. This data shows a greeting to her sister and it regarded as a greeting of expressive type of speech act.

\section{Data 2}

Elsa! Elsa! It's me, Anna... your sister who didn't mean to make you freeze the summer. I'm sorry. It's all my f-f-f-f-f-f-fault.

The words in bold are expressive because it shows that the speaker expresses her apology to her sister because she makes her sister angry and froze many things include the Arendelle, and run away to the mountain alone, as Finegan (2011) said that expressives show the speaker's psychological state or manner: e.g. apologies. On definition, we can see a relationship of it. This data shows an apology to her sister because she made her sister ran away and it regarded as an apology of expressive type of speech act.

\section{Data 3}

... I'm so sorry about what happened. If I'd known-

The words in bold are expressive because it shows that the speaker expresses her apology to her sister and caused her to run away to the mountain and get angry so the magic means to curse all the things including her and her young sister that threatened to die with a frozen heart, as Finegan (2011) said that expressives show the speaker's psychological state or manner: e.g. apologies. On definition, we can see a relationship of it. This data shows an apology to her sister and it regarded as an apology of expressive type of speech act.

\section{CONCLUSION}

From the table shown above, it can be seen that the type of speech act in Frozen the Movie are mostly representatives which are 38 statements, the second is directives at 32 sentences, the next is expressives at 10 and the last is commissives at 3 sentences. It shows that the character of the movie represents a situation. Considering that this movie is a comedy, animated movie. While directives type of speech act is the most speech act was spoken in the movie. The sentences that appear in the conversation of related character is mostly about the commands and request, as the movie is about the kingdom, and the related character is a Princess of the kingdom. The next type is expressives, this type does not seem to appear too often, the last appearance of the type of speech act is commisives, the rare type of speech act. The most scene of the movie is the journey of the related character which is the Princess to search her sister.

\section{ACKNOWLEDGMENTS}

Alhamdulillah the writers say for the completion of this research under the title "Speech Act of Frozen the Movie Script" all of the efforts that the writers put in this project that is given by Allah SWT and thank you to IKIP Siliwangi for giving the opportunity to publish this research. 


\section{REFERENCES}

Creswell, John W. (1997). Research Design Qualitative \& Quantitative Approaches. SAGE Publications.

Dewi, M. W., Hernawan, K. F., \& Apsari, Y. (2019). Thematic Progression in Students' Descriptive Text. PROJECT (Professional Journal of English Education), 2(2), 227-233.

Finegan, Edward. (2011). Language: Its Srtucture and Use. 6th ed. Michael Rosenberg. https://books.google.co.id/books?id=qXr4W5RC5noC\&pg=PA304\&lpg=PA304\&dq=re presentatives+represent+a+state+of+affairs:+assertions, + statements, +claims \&source $=b 1$ \&ots=3uzO32BxH1\&sig=ACfU3U22ilteIbHkeItVBxNYaQ8HpDeNAQ\&hl=en\&sa=X \&ved=2ahUKEwjW5PLVibThAhUzjOYKHVB.

Ilyas, Sanaa, and Qamar Khushi. (2012). "Facebook Status Updates : A Speech Act Analysis." Academic Research International 3(2 ISSN-L: 2223-9553, ISSN: 2223-9944): 500-507. http://www.savap.org.pk/journals/ARInt./Vol.3(2)/2012(3.2-63).pdf.

Kiuk, Paswasari Yuani, and Imam Ghozali. (2018). "Speech Act Analysis in Desmond's Conversation In 'Hacksaw Bridge' Movie." Director 15(2): 2017-19. https://www.uam.es/gruposinv/meva/publicaciones jesus/capitulos_espanyol_jesus/2005_motivacion para el aprendizaje Perspectiva alumnos.pdf\%0Ahttps://www.researchgate.net/profile/Juan_Aparicio7/publication/2535 71379_Los_estudios_sobre_el_cambio_conceptual_.

Kusnandar, Agus, and Tria Fatimah. "An Error Analysis of the Use of Preposition of Time (in, on, At)." : 3-13.

Lisdawati, Ida, and Trisnendri Syahrizal. (2012). "Students 'Perception in Applying Lesson Study in Teaching Introduction to Linguistics."

Tauchid, Ahmad, and Dwi Rukmini. (2016). "The Performance of Expressive Speech Acts as Found in Wayne Rooney’s Facebook.” English Education Journal 6(1): 1-10. 